[RAdiocarbon, Vol 22, No. 4, 1980, P 1064-1072]

\title{
NANCY NATURAL RADIOCARBON MEASUREMENTS VI
}

\author{
RENÉ COPPENS, BERNARD GUILLET*, \\ ROBERT JAEGY, and PIERRE RICHARD
}

Laboratoire de Radiogéologie, Ecole Nationale Supérieure de Géologie

Appliquée et de Prospection Minière, BP 45254001 Nancy, France

The following list includes some measurements made during 1978 and 1979 in the radiocarbon laboratory of the Ecole Nationale Supérieure de Géologie Appliquée et de Prospection Minière (ENSG) de Nancy. Equipment, measurement and treatment of samples are as reported previously ( $\mathrm{R}, 1979, \mathrm{v} 21, \mathrm{p} 453-464)$ where the sample is synthesized to benzene. Radiocarbon ages are calculated using the ${ }^{14} \mathrm{C}$ half-life of 5568 years and $95 \%$ activity of NBS oxalic acid is used as modern standard. Anthracite coal and Merck commercial benzene are used for the dead carbon run.

Counting errors are expressed at $1 \sigma$ confidence level. AD/BC* dates are corrected using the half-life of 5730 years and according to the MASCA correction curve (Ralph, Michael, and Han, 1973). Description and comments are generally based on information supplied by submitters.

\section{SAMPLE DESCRIPTIONS}

I. ARCHAEOLOGIC AND HISTORIC SAMPLES

\section{A. France}

\section{Château de la Hunaudaye, Plédéliac, Côtes-du-Nord}

Castle destroyed in 1347 and rebuilt soon after. $\mathrm{N}$ part was modified about 1420 and two houses were built, the first in the 16th century and the second in the 17th century. Castle was set on fire by revolutionists in 1793 (Delumeau, 1969; 1971).

Ny-547.

$$
570 \pm 80
$$

Carbonized wood. Coll by J Y Gervais under flagstone of castle yard; subm 1978 by $\mathrm{P}$ Henry. Comment: ${ }^{14} \mathrm{C}$ date agrees with repairs about 1420.

Ny-548.

$$
320 \pm 80
$$

Carbonized wood. Same origin as $\mathrm{Ny}-547$. Comment: ${ }^{14} \mathrm{C}$ date agrees with known date of building in 16th century.

Ny-669. Avioth, Meuse

$$
710 \pm 80
$$

Head of a wooden statue. Subm 1979 by R Sommesous, parson of Avioth, 55 Montmédy, France. May belong to old wooden statue. Possibly a more recent copy (Vigneron, 1972; 1979). Comment: ${ }^{14} \mathrm{C}$ date does not conflict with first hypothesis ( $c$ Ny-336, R, 1978, v 20, p 63).

* Centre de Pédologie Biologique, Nancy-Vandoeuvre 
Jabreille-les-Bordes series, Lieu-dit Le Chatelard (Haute-Vienne)

Samples date rampart of fence. Coll and subm by J M Desbordes, Dir Antiquités Hist Limousin, Limoges, France. Estimated age: Gallo-Roman period.

\section{Ny-555.}

Charcoal. Foundations of W part of rampart.

Ny-556.

Charcoal. Middle of $\mathrm{W}$ part of rampart.

Ny-557.

$1690 \pm 80$ AD 270 *

Charcoal. Upper part of $\mathrm{W}$ part of rampart.

Ny-671.

$2190 \pm 270$

Charcoal. Core of the W part of rampart.

330 в *

Ny-670.

$2150 \pm 180$

Charcoal. Shoulder of fence, S part, median level.

Ny-672.

$1920 \pm 180$

Charcoal. Shoulder of fence, $S$ part, lower level.

AD 60 *

General Comment (JMD): ${ }^{14} \mathrm{C}$ dates agree with expected age (early Roman age for construction of hill-fort).

\section{Solignac series, Haute-Vienne}

Coll and subm 1979 by J M Desbordes.

Ny-634.

$970 \pm 80$

Charcoal. Estimated age: 10th century.

AD 1010*

Carbonized wood from sepultures close by the apse of a church dedicated in 1143.

Ny-674. Sepulture 0

Ny-695. Sepulture 1

Ny-696. Sepulture 2a

Ny-693. Drilling

General Comment: dates agree with expected age.
$340 \pm 110$

AD 1490 *

$730 \pm 100$

AD 1230 *

$1030 \pm 90$

AD 950 *

$840 \pm 110$

AD 1140 * 


\section{Ny-635. Javerdat, Haute-Vienne}

Coll 1978 by G Lintz; subm by J M Desbordes. Charcoal. Estimated age: 11th or 12th century. Comment (JMD): dates agree with age of broken pottery.

\section{Ny-552. Tarnac, Corrèze}

$1760 \pm 80$

Charcoal at foot of tumulus (No. 5). Coll 1978 by G Lintz; subm by J M Desbordes. Estimated age: Tène or Roman period. Comment (JMD): no material. ${ }^{14} \mathrm{C}$ gives one and only date.

Ny-646. La Vallade Saint Victor, Creuse

$$
1320 \pm 90
$$

Charcoal coll 1978 by Valladas; subm by J M Desbordes. May date early ploughing.

\section{B. Italy}

\section{Monte Amiata district series, Grossetto and Sienna}

Oak from regular timbering of shallow seated mines. Discovered 1970 by O Strappa; coll and subm 1978 by F Saupé.

First sample

Ny-411.1 $5730 \pm 100$

Ny-411.2 $5720 \pm 110$

Second sample

Ny-411.3 $5720 \pm 100$

Ny-411.4 $5710 \pm 100$

Ny-411.5 $5770 \pm 100$

Comment: Mean: 5730 BP. Much too old to be attributed to one of known civilizations in Italy.

Mofettes - Monte Amiata dist, Grossetto and Sienna Prov, Italy. Coll and subm 1978 by F Saupé.

Ny-526. $22,570 \pm 1000$ Sienna.

Drill hole Sienna 2. Dismantled power-plant of Piancastagnaio,

Ny-524.

$>41,000$

Drill hole No. 10, 12th level, Solforate mine.

Ny-525.

$>41,000$

Drill hole $100 \mathrm{~m} \mathrm{~N}$ of former mine of Argus.

Ny-522.

$\mathbf{3 0 , 5 8 0} \pm \mathbf{1 0 0 0}$

Drill hole ENEL "PN 4" (open tank).

General Comment: two emanations have a high pressure and show virtually no ${ }^{14} \mathrm{C}$ (Ny-524,-525). Two others have a pressure close to 
atmospheric and small amounts of ${ }^{14} \mathrm{C}$ were introduced by atmospheric contamination (Ny-522,-526).

Living plants (trees, bushes, and reeds) growing near volcanic emanations. Coll and subm by F Saupé 1978.

Ny-483.

$540 \pm 80$

Alder (Alnus sp), S bank of Rondi naia Creek, front of blowing exhaust shaft of Pietrineri mine, Sienna.

Ny-484.

$370 \pm 80$

Cherry. A few $m$ from S Giovanni shaft, Sienna.

Ny.519.

$4350 \pm 90$

Wild cherry (Cerasus sp). Same as above.

Ny-516.

$1820 \pm 100$

Reed (Phragmites sp), immediately below Renaioli drift, next to putizze di Renaioli, Abetoso Creek, Grossetto.

Ny-517.

$2450 \pm 80$

Broom (Sarothamnus scoparius), Putizze di S Giovanni, Sienna.

Ny-518.

$4350 \pm 80$ Sienna.

Broom (Sarothamnus scoparius), Putizze di Pietrineri sink-hole,

Ny-535.

Modern

Blank oak (Quercus robur), NW of Palazzo di Pietrineri, outside of presently active mofette. Comment: dating of plants grown in vicinity of volcanic emanations emitting $\mathrm{CO}_{2}$ can yield pseudo-ages with too high results.

General Comment: study performed in order to check working hypothesis of volcanic contamination made to explain results of $\mathrm{Ny}-411$.

II. SOIL SAMPLES

Podzols

\section{Landes du Medoc series, France}

The Landes du Medoc, near Bordeaux, are characterized by a covering of quartz sand and the presence of groundwater very close to the surface. Soils here are fairly hydromorphic podzols. Righi (1977) studied the evolution of a podzolic sequence on a very short soil catena, $12 \mathrm{~m}$ long at Lagunan $\left(45^{\circ} 11^{\prime} 20^{\prime \prime} \mathrm{N}, 0^{\circ} 57^{\prime} 24^{\prime \prime} \mathrm{W}\right)$. Altitudinal difference between foot and top of hill is ca $30 \mathrm{~cm}$. Best drained podzols at top of hill have cemented spodic horizon $\left(\mathbf{B}_{2: \mathrm{h}}\right)$. Most hydromorphic podzols at foot of the hill have loose $B_{2 h}$ horizon. $B$ horizon samples, coll and subm by D Righi, Univ Poitiers, are further described according to vertical topographic sequence. Lateral distance between each sampled profile is ca $3 \mathrm{~m}$. 
Ny-609. Lagunan $3 B_{21 \mathrm{~h}}$

$1440 \pm 80$ 50 to $55 \mathrm{~cm}, \mathrm{C} \%: 1.8 \mathrm{C} / \mathrm{N}=19$

Ny-610. Same location, cement $B_{22 \mathrm{~h}}$ $2810 \pm 70$ 60 to $65 \mathrm{~cm}, \mathrm{C} \%: 1.5 \mathrm{C} / \mathrm{N}=39$

Ny-611. Same location $B_{3}$ $3390 \pm 80$ 75 to $80 \mathrm{~cm}, \mathrm{C} \%: 0.9 \mathrm{C} / \mathrm{N}=47$

Ny-612. Lagunan 3-2, cemented $B_{22 h}$ $2380 \pm 70$ 60 to $65 \mathrm{~cm}, \mathrm{C} \%: 1.0 \mathrm{C} / \mathrm{N}=36$

Ny-613. Lagunan 2, slightly cemented $3_{22 \mathrm{~h}}$ $2000 \pm 70$ 55 to $60 \mathrm{~cm}, \mathrm{C} \%: 1.1 \mathrm{C} / \mathrm{N}=34$

Ny-614. Same location $B_{3}$ $2440 \pm 70$ 65 to $70 \mathrm{~cm}, \mathrm{C} \%: 0.7 \mathrm{C} / \mathrm{N}=33$

Ny-615. Lagunan 2-4 $B_{2 \mathrm{~h}}$ 40 to $45 \mathrm{~cm}, \mathrm{C} \%: 1.9 \mathrm{C} / \mathrm{N}=22$

Ny-616. Lagunan $4 B_{2 h}$ 30 to $35 \mathrm{~cm}, \mathrm{C} \%: 1.9 \mathrm{C} / \mathrm{N}=22$

Ny-617. Same location $B_{3}$

40 to $45 \mathrm{~cm}, \mathrm{C} \%: 0.9 \mathrm{C} / \mathrm{N}=23$

$770 \pm 80$

General Comment: most striking aspects of series are very good agreement between longest mean residence times of organic matter (Ny-610-614) and micromorphologic features of corresponding horizons. In these horizons the $\mathrm{N}$ poor organic matter is assoc with mainly alumina-polymers to form grain coatings which solder skeleton grains together. In the other horizons, better biologic activity is demonstrated by shorter mean residence times, lower $\mathrm{C} / \mathrm{N}$ ratios of organic matter and, above all, a microstructural organization of silt and organic matter as pellets and aggregates (Righi and Guillet, 1977).

\section{Bassin Parisien series, France}

During the Pleistocene and Holocene the sands of the Tertiary (Auversian Beauchamp sands and Stampian Fontainebleau sands) were more or less recovered and mixed by silt. Even in the case of a moderate sitation rate $(\cong 10 \%)$ the developed soils are podzols or podzolic soils in which an $\mathrm{A}_{2}$ horizon is slightly differentiated. Samples coll near Villers Cotterets $\left(49^{\circ} 13^{\prime} 48^{\prime \prime} \mathrm{N}, 2^{\circ} 59^{\prime} 40^{\prime \prime} \mathrm{E}\right)$ and Fontainebleau $\left(48^{\circ} 25^{\prime} 44^{\prime \prime}\right.$ N, $\left.2^{\circ} 39^{\prime} 10^{\prime \prime} \mathrm{E}\right)$ and subm 1976 by A M Robin, Univ Paris VI.

Ny-510. Villers Cotterets $11 \mathrm{~B}_{\mathrm{h}}$ $50 \pm 90$ 30 to $40 \mathrm{~cm}, \mathrm{C} \%: 0.6 \mathrm{C} / \mathrm{N}=24$

Ny-501. Fontainebleau $3 B_{h}$ $210 \pm 50$ 40 to $55 \mathrm{~cm}, \mathrm{C} \%: 0.5 \mathrm{C} / \mathrm{N}=24$ 
Ny-511. Villers Cotterets $12 \mathrm{~B}_{\mathrm{h}}$

33 to $45 \mathrm{~cm}, \mathrm{C} \%: 0.3 \mathrm{C} / \mathrm{N}=18$

Ny-512. Villers Cotterets $13 B_{21 \mathrm{~h}}$

63 to $70 \mathrm{~cm}, \mathrm{C} \%: 1 \mathrm{C} / \mathrm{N}=19$

Ny-514. Same profile $B_{s}$

Modern

70 to $75 \mathrm{~cm}, \mathrm{C} \%: 0.8 \mathrm{C} / \mathrm{N}=26$

Ny-508. Villers Cotterets $9 B_{h}$

65 to $75 \mathrm{~cm}, \mathrm{C} \%: 1.6 \mathrm{C} / \mathrm{N}=29$

Ny-509. Same profile $B_{s}$

75 to $85 \mathrm{~cm}, \mathrm{C} \%: 0.8 \mathrm{C} / \mathrm{N}=27$

Ny-502. Villers Cotterets $1 B_{h 1}$

30 to $37 \mathrm{~cm}, \mathrm{C} \%: 4.7 \mathrm{C} / \mathrm{N}=52$

Ny-503. Same profile $B_{2 h}$

$1820 \pm 100$

77 to $85 \mathrm{~cm}, \mathrm{C} \%: 1.6$

Ny-507. Villers Cotterets $3 B_{\text {h2 }}$

120 to $130 \mathrm{~cm}, \mathrm{C} \%: 0.9$

Ny-504. Fontainebleau, buried II A

$1750 \pm 90$

40 to $55 \mathrm{~cm}, \mathrm{C} \%: 2.7$

Ny-505. Same profile II $B_{21 \mathrm{~h}}$

$1660 \pm 90$ 100 to $110 \mathrm{~cm}, \mathrm{C} \%: 1.5$

Ny-506. Same profile, II $B_{22 h}$

$2510 \pm 100$

General Comment: series was classified according to two criteria. First seven dates correspond to podzols presently under deciduous forest (oak and beech) that received weak eolian silt contamination. With respect to low mean residence time of organic carbon, these forest podzols behave as biologically active soils with relatively low $\mathrm{C} / \mathrm{N}$ ratio. The other profiles are in steady state equilibrium with a degraded vegetation (Pinus silvestris, Calluna vulgaris) and received no silt contamination. Although the last podzols are not necessarily older than the forest podzols, the large quantity of organic matter is biologically more stable since the mean residence times in $B_{h}$ horizons are close to 2000 years. Note also the higher $\mathrm{C} / \mathrm{N}$ ratio of the organic matter. According to Robin (1979) clay mineral composition must be considered in explaining the difference. In forest podzols, weathering ferromagnesian clay minerals must liberate iron which stimulates biologic activity and catalytic decay of organic matter. For the second group of podzols, the only clay minerals are kaolinite and feldspars, the weathering of which releases alumina. It is now well known (Guillet, 1979) that Al-hydroxypolymers assoc with organic matter in $B_{h}$ skeleton grain coatings have a depressive effect on mineralization and decay of organic matter. 
History of vegetation during Holocene in estuary of the Loire $\mathrm{R}$ and in "Grande Brière" Loire Atlantique, France (Visset, 1979). Samples coll and subm 1977-1979 by L Visset.

\section{Trignac, Canal de Fougères series}

Palynology shows invasion of site by Alnus, forming a real alnetum that declines towards the end of the Sub-Boreal and disappears at limit of Sub-Boreal-Sub-Atlantic.

Ny-494.

$4180 \pm 90$

Brown peat, Alnetum, depth, -154 to $-160 \mathrm{~cm}$.

Ny-493.

$3770 \pm 90$

Brown peat, declining alnetum, depth, -125 to $-131 \mathrm{~cm}$.

Ny-492.

$3480 \pm 90$

Black peat, disappearance of alnetum, depth, -119 to $-125 \mathrm{~cm}$.

\section{Tree series}

At some time, increase of fresh-water level causes formation of a phragmites bog. Quercetum cannot survive in this anaerobic environment and gradually declines. The trees die progressively.
Ny-496. Trignac
$4000 \pm 80$
Ny-523. Trignac
$4120 \pm 90$
Ny-544. Rozé
$4100 \pm 90$

General Comment: trees of the same area but originating from different sites have been dated by other laboratories: (Sa-35: $4040 \pm 300$ вP; Sa-40: $3880 \pm 300$ вр; Sa-46: $4260 \pm 300$ вP; Gif-3536: $4230 \pm 110$ вр). Close correspondence of all results confirm validity of date.

\section{Ny-495.}

$4260 \pm 90$

Organic mud, depth, -180 to $-185 \mathrm{~cm}$. Comment: agrees with results obtained from trees (Ny-496,-523,-544). Brown peat, Ny-494, does not show meaningful differences with $\mathrm{Ny}-495$, indicating short peaty mud period.

\section{Ny-491.}

$2110 \pm 80$

Black peat from top of layer, depth, -45 to $-49 \mathrm{~cm}$. Comment: interruption of peat formation by sediments of tidal mud, as a result of rising sea level and penetration in bog (cf Ny-6, R, 1968, v 10, p 122).

\section{Pierre blanche series}

Ny-476.

$2280 \pm 80$

Brown peat.

Ny-475.1.

$2120 \pm 80$

Black peat. 
Ny-475.2.

Black peat.

General Comment: estimated age: brown peat, 4000 вр, black peat, 3500 BP. Dates corresponding to Sub-Atlantic disagree with pollen record and geologic history of site.

\section{Rozé series}

Ny-545.

$3340 \pm 90$

Bark and wood of birch in peat in transitional brown peat - black peat during disappearance of Betuletum. Comment: date agrees with Ny-492.

Charcoal fragments at the base of black peat in a well characterized level of a fire.

Ny-546.1.

$3570 \pm 80$

Ny-546.2.

$3490 \pm 90$

Ny-546.3.

$3390 \pm 80$

Comment: date of 3400 can be retained in agreement with $\mathrm{Ny}-492$ and $\mathrm{Ny}-545$.

\section{Ny-633. Ile d'Errand}

Oak wood fragment.

\section{Ny-474. Quatre canaux}

$6830 \pm 100$

Drilling $-15.55 \mathrm{~m}$ WGF. Oisters. Comment: date agrees with palynologic results and places this sediment ( $1 \mathrm{~m}$ thick) around Middle of Atlantic period. R.

History of the vegetation of the Pleistocene in the valley of the Loire

\section{Ny-543.1. Roc-en-Pail}

$19,400 \pm 560$

Ox bone.

Ny-543.2.

$19,510 \pm 620$

Same sample. Comment: prehistoric site of Mousterian at Chalonnes. sur Loire (assumed age: 35,000 yr).

\section{REFERENCES}

Delumeau, J, 1969, Histoire de la Bretagne: Toulouse, private ed, p 148. 1971, Documents de l'histoire de la Bretagne: Toulouse, privat ed, p 176-178. Guillet, Bernard, 1979, Etude du renouvellement des matières organiques des sols par les radioisotopes $\left({ }^{14} \mathrm{C}\right)$, in Bonneau, $M$ and Souchier, B, eds, Pedologie: Constituants et propriétés: Masson pub, p 210-226.

Ralph, E K, Michael, H N, and Han, M C, 1973, Radiocarbon dates and reality: MASCA Newsletter, v 9, no. 1, p 1-19.

Righi, D, 1977, Genèse et évolution des podzols et des sols hydromorphes des Landes du Mćdoc: Doctoral thesis, Poitiers, $144 \mathrm{p}$.

Righi, D and Guillet, Bernard, 1977, Datations par le carbone 14 natural de la matière organique d'horizons spodiues de podzols des Landes du Médoc (France), in Soil organic matter studies: IAEA, Vienna, v 2, p 187-192. 
Robin, A M, 1979, Genèse et évolution des sols podzolisés sur affleurements sableux du Bassin Parisien: Doctoral thesis, Nancy, 173 p.

Saupé, Francis, Strappa, Osvaldo, Coppens, René, Guillet, Bernard, Jaegy, Robert, 1980, A possible source of error in ${ }^{14} \mathrm{C}$ dates: volcanic emanations (examples from the Monte Amiata district, Provinces of Grosseto and Sienna, Italy), in Stuiver, Minze and Kra, Renee, eds, Internatl radiocarbon conf, 10th, Proc: Radiocarbon, v 22, no. 2, p 525-531.

Vigneron, Constant, 1972, L'insigne église Notre-Dame d'Avioth: Dun-sur-Meuse, France, Vigneron ed.

1979, La recevresse, d'abord auditoire. Les 15 statues des piliers de la grand'nef du début du XV ${ }^{\text {emo }}$ siècle: Dun-Sur-Meuse, France, Vigneron ed.

Visset, Lionel, 1979, Recherches palynologiques sur la végétation pléistocène et holocène de quelques sites du district phytogéographique de Basse-Loire, Thèse Doctorat Sci: Soc Sci Nat Ouest France, Nantes, supp sér, v 1, 282 p. 